\title{
FEDERAL AND STATE REGULATION OF TRADE-MARKS
}

\section{Bartholomew Diggins*}

The Lanham Trade-Mark Act of $1946^{1}$ is the result of years of work by business, bar, and Congress to secure comprehensive and uniform legislation in the field of trade-marks and unfair competition. ${ }^{2}$ Prior to the effective date of the Lanham $\mathrm{Act}^{3}$ the law of trade-marks and unfair competition was a patchwork of federal and state law. It is the purpose of this paper to examine the extent to which the Lanham Act has brought order and uniformity to the unsettled and unsatisfactory conditions which preceded its enactment.

\section{Historical Background}

The law of unfair competition, of which the law of trade-marks is a part, ${ }^{4}$ is necessarily a flexible and expanding field. The need for effective protection against unfair competition expands and diversifies as business itself expands and diversifies; unfair trade tactics are limited only by the ingenuity of the unfair trader. Historically and necessarily, the courts have lagged in affording protection against unfair trading, largely because they have had no official declarations of policy to guide them, and standards of business behavior could be formulated only by trial and error after the damage was done. 5 As one authority puts it,

Experience shows that by the time the judicial machinery arrives at a place where the pirate was yesterday, ready to deal with him, that elusive person has moved forward and is still a little ahead-at a place where the courts will not reach until tomorrow-and is there engaged in doing something which will enable him to advantage himself at someone's else expense in some manner hitherto unthought of. ${ }^{6}$

* B.S. in E.E. 1929, Catholic University of America; LL.B. 1933, Georgetown University. Member of the District of Columbia bar. Examiner, United States Patent Office, 1929-34; Special Assistant to the Attorney General, I941-46.

${ }^{1}$ Act of July 5, I946, 60 STAT. 427, 15 U. S. C. \$105I (1946).

2 The term "unfair competition" is a misnomer since many acts not strictly competitive are actionable. In Harry D. Nims, The Law of Unfair Competition and Trade-Marks (3d ed. I936), seven pages ( 6 to 22) are devoted to "Definitions of Unfair Competition," and in Walter Denenderg, Trade-Mark Protection AND UNFAIR Trading (1936), the more accurate term "unfair trading" is used to describe the cause of action. However, by widespread usage, the term "unfair competition" has acquired lcgal standing, and will be used in this paper with the understanding that it includes acts and practices not strictly competitive.

${ }^{3}$ July 5 , 1947.

- Hanover Star Milling Co. v. Metcalf, 240 U. S. 403, 4r3 (I916); United Drug Co. v. Rectanus, 238 U. S. 90,97 (19r8).

'Handler, Unfair Competition, 21 Iowa L. Rev. I75, 179 (1936).

' Rogers, New Concepts of Unfair Competition under the Lanham Act, 38 T. M. Rep. 259, 270 (I948). 
The development of the substantive law of unfair competition has been primarily by judicial decision. Both state and federal courts have afforded relief against unfair competition. ${ }^{7}$ Vested trade-mark rights have been recognized and protected by the courts of all states irrespective of state or federal registration, and, as might be expected, the decisions of the different state and federal courts are not consistent or uniform. 8 As business grew and developed, this inconsistency and lack of uniformity became disturbing to businessmen, so that when the first federal law relating to trade-marks ${ }^{9}$ was held unconstitutional, ${ }^{10}$

Congress was flooded with proposed new legislation on the subject, even including a resolution for an amendment to the Constitution of the United States granting to Congress express power to regulate the use of trade-marks. ${ }^{11}$

Most of the states have had laws providing for the registration of trade-marks ${ }^{12}$ and have afforded some protection for marks so registered, ${ }^{13}$ but state law is necessarily ineffective to protect interstate business. Registration under state laws was not essential even in so far as local business was concerned. The Association of the Bar of the City of New York studied the matter of state registrations, and, as a result of its study, issued a bulletin which contains the following statement:

Vested trade-mark rights are recognized and protected by the courts in all the states irrespective of state or federal registration. Therefore the statement . . . that state registration is necessary in order adequately to protect trade-mark rights is not true. State registration is helpful only in exceptional cases and the trade-mark owner should not be burdened with the large expense involved in securing such registration except in unusual cases. ${ }^{14}$

Not only were the trade-mark registration laws of the states ineffective, but the Committee on Patent, Trade Mark and Copyright Law of the American Bar Association described most of such laws as "pernicious."15 Referring to certain trade-mark registration laws pending in New York, Maryland, and Nevada, this committee said that they "would provide work for lawyers and state registration specialists but would be detrimental to trade-mark owners and to the public."16

Even the common law of the states was uncertain and unsatisfactory, largely because of the scarcity of precedents. Trade-mark and unfair competition cases

'Handler, supra note 5 , at 179.

${ }^{8}$ For a striking example of this divergence on substantially similar facts, cf. Putnam Nail Co. v. Bennett, 43 Fcd. 800 (C. C. E. D. Pa. I890), with Putnam Nail Co. v. Dulaney, 140 Pa. St. 205 , 21 Atl. 39 I (189I).

Act of July $8,1870,16$ Stat. 198.

${ }^{10}$ Trade Mark Cases, 100 U. S. 82 ( 1879 ).

${ }^{12}$ Rep. No. 3147 on H. R. I6560, 58th Cong,, 3d Sess. (1904), reprinted in I7 J. PAT. OFF. Soc's 120, 123 (1935).

12 I7 J. Pat. Off. Soc'y 120, 133 (I935).

13 Walter Derengerg, Preparing for the New Trade Mark Law (Research Institute of America, I946).

${ }_{14}$ Bulletin Regarding Circulars Recently lssued by Certain Self-Styled "Trade Mark Specialists," reprinted in 17 J. Par. OFF. Soc'r 740, 74I (1935).

${ }^{16} I d$. at 736 .

${ }^{10} \mathrm{Id}$. at 737 . 
were limited to the commercial centers and the decided cases were few and far from comprehensive. $^{17}$

Because of pressure from business, Congress passed the Trade Mark Act of rg05. ${ }^{18}$. One of the major reasons urged for the passage of the bill was "that the defects in existing law relating to such [interstate] use of trade marks will be remedied." 10

The Trade Mark Act of 1905 , however, fell far short of its objective of remedying "the defects in existing law." The benefits of that Act were procedural only, and the nature and scope of the right in a registered trade-mark remained a common-law matter. ${ }^{20}$ The Trade Mark Act of 1905 expressly preserved the common-law rights in all trade-marks, whether registered or unregistered. ${ }^{21}$

The Act of 1905 did give the federal courts jurisdiction in cases involving registered trade-marks, ${ }^{22}$ and cases involving such marks were usually brought in the federal courts. In addition, as businesses expanded from local to interstate and international, many, if not most, of the cases involving unregistered trade-marks and unfair competition found their way into the federal courts by reason of diversity of citizenship. ${ }^{23}$ While the courts paid lip-service to the rule that substantive rights in trade-marks rested upon the laws of the several states, ${ }^{2-4}$ nevertheless, because most of the trade-mark and unfair competition cases were in the federal courts, a great body of federal law was built up with no apparent regard for state precedents. Practically, if not legalistically, there was a substantive federal common law of trade-marks and unfair competition, and this body of federal decisions to some extent provided a consistent and comprehensive guide for lawyers and businessmen. ${ }^{25}$

Continuous efforts by state legislatures to pass compulsory registration statutes were feared and resented by businessmen ${ }^{20}$ and threatened to result in "an intolerable

${ }^{17}$ Rogers, supra note 6 , at 263 .

${ }^{18} 33$ Stat. 724 (I905), as amended, 52 Stat. 638 (I938), I5 U. S. C. $\$ 81$ ee seq. (I946).

10 I7 J. Pat. OfF. Soc'x 133 (1935).

${ }^{20}$ Estate of P. D. Beckwith v. Commissioner of Patents, 252 U. S. 538 (1920). "Registration of a trade-mark under the Trade-Mark Act of 1905 neither enlarges nor abridges the registrant's common-law rights in the mark." Dwinell-Wright Co. v. National Fruit Product Co., 54 U. S. P. Q. I49, 151,129 F. 2 d 848,85 (C. C. A. Ist r942).

2133 Stat. 730 (I905), 15 U. S. C. $\$ 103$ (1946).

${ }^{22} 33$ STAT. 728 (rgo5), as amended, 49 STAT. 1921 (1936), 15 U. S. C. $\$ 97$ (1946).

23 See note I7 supra.

${ }^{24}$ United Drug Co. v. Rectanus, 248 U. S. 90 (1918).

${ }^{25}$ Zlinkoff, Erie v. Tompkins: In Relation to the Law of Trade-Marks and Unfair Compctition, 32 T. M. REP. 81, 85 (r942), refers to the body of federal decisions as "an unusually large and important body of jurisprudence." In Philco Corporation v. Phillips Mfg. Co., 133 F. 2d 663, 666 (C. C. $A$. $7_{\text {th }}$ 1943), Judge Kerner said: "But in another sense there has been a federal general common law and cases have been 'governed by federal law' within the meaning of the Erie doctrine, for federal courts have exercised independent judgment as to what 'the common law' was in all cases in the ficld."

28 "Businessmen have a viewpoint different very often from the lawyer's viewpoint. We are annoyed very much by State legislation and we are annoyed by picayunes who go out and try to scare the manufacturers into registration under State laws with some reason which while it sounds plausible at the time does not hold water." Testimony of W. H. Stanley, vice president, William Wriglcy Jr. Co., in Hearings before the Subcommittee on Trade-Marks of the House Committee on Patents on $H$. R. I02, H. R. 5461, and S. 895, 77th Cong., Ist Sess. 137, 138 (1941). 
mess, because we have 48 separate sovereignties to deal with, each legislating as it sees fit with respect to marks within its borders regardless of where those marks originate." 27

There was no substantial question as to the general validity of state law in this field, but at least until 1932 there was serious doubt as to the power of Congress to enact substantive legislation relating to trade-marks and unfair competition. ${ }^{28}$ Whether or not Congress had the power to enact such substantive legislation, there was no doubt that it had refrained from doing so. ${ }^{29}$ Trade-marks and unfair competition are subjects over which the federal and state governments have concurrent jurisdiction, and, since Congress had failed to act in substantive matters, state law governed the substantive rights in these matters.

Beginning with the Trade-Mark Act of $\mathrm{r} 88 \mathrm{r},{ }^{30}$ the efforts of Congress to legislate with respect to trade-marks indicate a feeling of uncertainty as to its powers. Congressional legislation treated procedure rather than substance, and, even procedurally, the legislation was piecemeal rather than comprehensive. As a result, the federal statutory law of trade-marks was scattered through a number of statutes ${ }^{31}$ and those statutes taken together were woefully inadequate. ${ }^{32}$ As early as 1928 the need for codification and modification of the federal trade-mark laws was recognized and made the subject of a study by the Committee on Patents, Trade Marks and Copyrights of the American Bar Association. ${ }^{33}$

The lack of uniformity in the trade-mark and unfair competition laws of the different states and the inadequacy of federal law were highlighted when, in $193^{8}$, the Supreme Court in Erie Railroad v. Tompkins ${ }^{34}$. -required the federal courts to apply the law of the state in which they sit. In the first trade-mark case considered by the Supreme Court after the Erie decision, Kellogg Company v. National

Iz "Most of the States were greedy for revenue, naturally enough, and here was an opportunity to make the outsider pay revenue." Statement of Edward S. Rogers in Hearings before the Subcommittee on Trade-Marks of the House Committee on Patents on H. R. go41, 75th Cong., 3d Sess. 11, 12, 13 (1938).

${ }^{38}$ American Trading Co. v. Heacock Co., 285 U. S. 247 (I932).

${ }^{20}$ See notes 20 and 21 supra.

${ }^{30}$ See note 9 stupra.

${ }^{32}$ I5 U. S. C. $\$ 8 \mathrm{I}-\mathrm{Iog}(1946)$ ). “. . We have had a number of Federal statutes. The first one was the act of 1870 . That was declared unconstitutional. It was followed by the act of 1881 , which applicd to trade-marks used in foreign commerce and commerce with the Indian tribes, and was based on the treaty-making power. That was supplemented or superseded, I should say, by the Act of rg05, which was based on the commerce clause and embraced trade-marks used in interstate commerce. That was supplemented by the Act of $\mathbf{1 9 2 0}$, and both acts have been amended from tirne to time. The result is we now have a rather confused situation which is diffcult to understand, because there are 9 or ro separate trade-mark acts and you find trade-mark provisions in such unexpected places as the Tariff Act, the Act to Incorporate the Boy Scouts, and the Act to Incorporate the Red Cross, and it is hard for anyone to find out what the Federal statutory law is, because it is so badly scattered." Statement of Edward S. Rogers in Hearings, supra note 27 , at 12.

${ }^{32}$ One of the most outstanding inadequacies is the failure of the Trade-Mark Act to recognize secondary-meaning marks adopted after 1895 (so-called Ten Year proviso). 33 STAT. 725 (I905), as amended, 43 Strit. 647 (I924), 15 U. S. C. $\$ 85$ (r946).

${ }^{83}$ See note 27 supra.

${ }^{34} 304$ U. S. 64 (1938). 
Biscuit Company, the court specifically stated that the Erie doctrine applied in trade-mark cases. ${ }^{36}$

The effect of the Erie decision is well illustrated in the decisions of the Court of Appeals for the Seventh Circuit. In Sinko v. Snowv-Craggs Corporation, ${ }^{37}$ that court based its decision upon the general principle that "equity will protect the honest, and restrain the dishonest, trader," ${ }^{38}$ basing its decision exclusively upon decisions of the federal courts and one decision rendered by Mr. Justice Holmes while on the Supreme Judicial Court of Massachusetts. Two years later this same court decided Addressograph-Multigraph Corporation v. American Expansion Bolt \&. Manufacturing Company. ${ }^{39}$ The complaint charged misappropriation of the plaintiff's business system. The district court, relying on the Supreme Court's decision in International News Service v. Associated Press, found all issues in favor of plaintiff and ordered an accounting of profits and damages. In reversing the district court, the Court of Appeals said:

It appears that the lower court decided the case upon general Federal law. At any rate, it is certain that the law of unfair competition, as announced by the courts of Illinois, was not applied. We are therefore at the threshold of our consideration met with defendant's contention that under Erie R. Co. v. Tompkins ... the law of the state, as announced by its courts, must be given effect...

There is little room for argument but that the District Court, as well as this court, must give application to the Illinois law of unfair competition....

... the law of unfair competition, as announced in Illinois, must be applied. ${ }^{40}$

The Court of Appeals found that under the law of Illinois, as announced by the Illinois courts, actionable unfair competition was limited to "palming off" and that therefore misappropriation of a business system was not actionable.

Recognition of the deficiencies in prior law was directly responsible for the passage of the Lanham Act. The report of the Senate Committee on Patents urged passage of the Act in the following language:

The theory once prevailed that protection of trade-marks was entirely a State matter and that the right to a mark was a common-law right. This theory was the basis of previous national trade-mark statutes. Many years ago the Supreme Court held and has recently repeated that there is no Federal common law. It is obvious that the States can change the common law with respect to trade-marks and many of them have, with the possible result that there may be as many different varieties of common law as there are

35 305 U. S. III (1938).

${ }^{30} \mathrm{Id}$., n. $\mathrm{n}$. It is interesting to note, however, that in Armstrong Paint \& Varnish Works v. NuEnamel Corporation, 305 U. S. 3I5 ( $\left.{ }^{9} 938\right)$, which is in the same volume of the Reports, the Supreme Court does not cite a single state decision nor refer to state law.

${ }^{37}$ I05 F. 2d 450 (C. C. A. 7 th 1939). While this case was decided more than a ycar after Erie Railroad Co. v. Tompkins, and eight months after the Erie doctrine was held applicable in trade-mark and unfair competition cases in Kellogg Co. v. National Biscuit Co., 305 U. S. 11 I (1938), apparcntly the court did not appreciate the application of the Erie doctrine and decided the case without reference to Illinois law.

${ }^{38} \mathrm{Id}$. at 452 .

${ }^{30} 124$ F. 2 d 706 (C. C. A. 7 th $x 94 \mathrm{I}$ ), cert. denied, 3 I6 U. S. 682 (194I).

${ }^{40} \mathrm{Id}$. at 708 . 
States. A man's rights in his trade-mark in one State may differ widely from the rights which he enjoys in another.

However, trade is no longer local, but is national. Marks used in interstate commerce are properly the subject of Federal regulation. It would seem as if national legislation along national lines securing to the owners of trade-marks in interstate commerce definite rights should be enacted and should be enacted now.

There can be no doubt under the recent decisions of the Supreme Court of the constitutionality of a national act giving substantive as distinguished from merely procedural rights in trade-marks in commerce over which Congress has plenary power, and when it is considered that the protection of trade-marks is merely protection to goodwill, to prevent diversion of trade through misrepresentation, and the protection of the public against deception, a sound public policy requires that trade-marks should receive nationally the greatest protection that can be given them. ${ }^{41}$

This statement, especially the reference to the need for "national legislation along national lines," shows a clear recognition of the fact that in the field of trade-marks and unfair competition uniformity is essential to protect and preserve commerce.

The power of Congress to regulate interstate and foreign commerce is clear, ${ }^{42}$ and doubt as to the power of Congress to regulate trade-marks and unfair competition could only be based upon doubt as to whether these subjects are within the commerce power. Whatever may have been the legal concept of commerce at the time of the Heacock decision, ${ }^{43}$ this concept has been considerably broadened since I933. As stated by Mr. Justice Rutledge, ${ }^{44}$

The aegis of federal commerce power continued to spread over and enfold other business so conducted, in both general and specific legislative exertions. Usually this was with judicial approval; and, despite notable instances of initial hostility, the history of judicial limitation of congressional power over commerce, when exercised affirmatively, has been more largely one of retreat than of ultimate victory.

The courts have recognized and sustained the power of Congress to regulate competitive practices under the Federal Trade Commission Act," and "unfair methods of competition" 46 under that Act include a variety of trade-mark situations. ${ }^{47}$ Trade-marks have been identified as the symbols "we purchase goods by," 48

${ }^{42}$ SEN. REP. No. 1333, 79th Cong., 2d Sess. (1946).

${ }^{12}$ U. S. Const. Art. I, $\$ 8$.

${ }^{43}$ See note 28 supra.

“Prudential Insurance Co. v. Benjamin, 328 U. S. 408, 415 (1946).

${ }^{4 E} 38$ Stat. 7X7 (IgI4), as amended, 52 StaT. III (I938), I5 U. S. C. \$4T (I946).

${ }^{10} 38$ Stat. 7I9 (I914), as amended, 52 Stat. roz8 (1938), 15 U. S. C. $\$ 45$ (1946).

${ }^{47}$ Handler, Unfair Competition, 2I IOWA L. REv. 775 (1936), lists a number of trade-mark or closely related practices which the Federal Trade Commission has banned or attempted to ban as "unfair methods of competition." Some of the more important are "False or misleading advertising," "misbranding," "passing off," "use of misleading trade names," and "giving products misleading names." Id. at $244,245,247$. The practices which the courts have condemned include "false advertising and misbranding," "misrepresentation of business status," "misrepresentation of origin," "simulation of trade marks and trade names." Id. at 248, 249. Handler does state, however, "It is rather doubtful whether orders forbidding trade mark and trade name simulation, except where the mark or name is inherently deceptive, will be sustained." Id. at 250 . This doubt apparently springs from the fact that the Commission functions to protect the public generally and that ordinary trade-mark infringement is a private wrong for which adequate remedies are provided. Sec Derenberg, The Patent Office As Guardian of the Public Interest in Trade-Mark Registration Proceedings, infra.

${ }^{88}$ Mishawaka Rubber and Woolen Mfg. Co. v. S. S. Kresge Co., 316 U. S. 203, 205 (1942). 
and press and radio are constant reminders of the intimate and inseparable relationship between the symbols and the trade itself. In Wickard $v$. Filburn ${ }^{40}$ the Supreme Court upheld the power of Congress to penalize the threshing of 239 bushels of wheat for home use because of the "effect on interstate commerce." It seems obvious that the integrity of trade-marks such as "Gold Medal"51 has a far greater effect on interstate commerce and more immediately and directly affects the whentpurchasing public than Filburn's 239 bushels of wheat. Thus, if it is within the power of Congress to regulate the latter, the former is also within that power.

With the defects and uncertainties of prior law and the need for uniform federal law in mind, Congress clearly and specifically stated the intent of the Lanham Act in the following language:

The intent of this Act is to regulate commerce within the control of Congress by making actionable the deceptive and misleading use of marks in such commerce; to protect registered marks used in such commerce from interference by State, or territorial legislation; to protect persons engaged in such commerce against unfair competition; to prevent fraud and deception in such commerce by the use of reproductions, copies, counterfeits, or colorable imitations of registered marks; and to provide rights and reme. dies stipulated by treaties and conventions respecting trade-marks, trade names and unfair competition entered into between the United States and foreign nations. ${ }^{52}$

It was thus the intent of Congress in the Lanham Act to deal with "registered marks,"53 "marks" which are entitled to registration, "trade-marks" w5 which may or may not be entitled to registration, "trade names,"5s and "unfair competition." Registered marks are to be protected "from interference by State, or territorial legislation," deceptive and misleading use of marks in commerce is to be made "actionable," "rights and remedies" are to be provided respecting trade-marks, trade names and unfair competition, and persons engaged in commerce are entitled to effective protection against unfair competition. ${ }^{57}$

Other sections of the Act corroborate and emphasize the breadth of the Lanham Act. Congress makes the Act applicable to "all commerce which may lawfully be

"3I7 U. S. III (1942).

${ }^{50} \mathrm{Id}$. at 125.

${ }^{62}$ France Miling Co. v. Washburn Crosby Co., 7 F. $2 d$ d04 (C. C. A. 2d 1925).

ba 6 o STAT. 443 , I5 U. S. C. $\$ 1127$ (1946).

53 The term "registered mark" means a mark registered in the United States Patent Office under this Act or under the Act of March 3, I881, or the Act of February 20, 1905, or the Act of March 19, 1920. The phrase "marks registered in the Patent Office" means registered marks. Sce note 52 supra.

"The term "mark" includes any trade-mark, service mark, collective mark, or certification mark entitled to registration under this Act whether registered or not. See note 52 sipra.

55 The term "trade-mark" includes any word, name, symbol, or device or any combination thereof adopted and used by a manufacturer or merchant to identify his goods and distinguish them from those manufactured or sold by others. See note 52 supra.

${ }^{86}$ The terms "rade name" and "commercial name" include individual names and surnames, firm names and trade names used by manufacturers, industrialists, merchants, agriculturists, and others to identify their businesses, vocations, or occupations; the names or titles lawfully adopted and used by persons, firms, associations, corporations, companies, unions, and any manufacturing, industrial, commercial agricultural, or other organizations engaged in trade or commerce and capable of suing and being sued in a court of law. See note 52 sispra.

E7 60 STAT. 443 , I5 U. S. C. \$1127 (1946). 
regulated by Congress," throughout all territory which is under the jurisdiction and control of the United States. ${ }^{\varpi 8}$ These broad statements show clearly and unmistakably that in the Lanham Act Congress intended to exercise its full power to regulate trade-marks and unfair competition to the end that the law in this field might be certain and uniform throughout the United States. The Lanham Act is "national legislation along national lines."

While the Lanham Act will necessarily affect the whole field of trade-mark and unfair competition law, only a few of the more important effects and changes can be considered in this paper. These more important effects are: (I) The effect on the jurisdiction of the federal courts; (2) the effect on the rules of decision for the federal courts; (3) the effect on state statutes relating to trade-marks or unfair competition; (4) the effect on rules of decision in state courts; and (5) the protection of rights existing at the time the Lanham Act became effective.

II

\section{Jurisdiction of the Federal Courts}

The jurisdiction of the federal courts in cases involving infringement of registered trade-marks presents no serious question. The federal courts had such jurisdiction under the Trade-Mark Act of $1905,{ }^{59}$ and such jurisdiction is continued under the Lanham Act. ${ }^{60}$ This jurisdiction attaches "without regard to the amount in controversy or to diversity or lack of diversity of the citizenship of the parties."

Jurisdiction involving unregistered trade-marks or trade names or unfair competion is, however, not so clear in the absence of diversity of citizenship of the parties and the requisite amount in controversy. It is certain that the existence of a question relating to trade-marks, trade names, or unfair competition did not constitute an independent ground for federal jurisdiction prior to the Lanham Act, ${ }^{62}$ and the question is whether the Lanham Act has changed the law in this respect.

Section 39 of the Lanham Act confers jurisdiction on the federal courts of "all actions arising under this Act, without regard to the amount in controversy or to diversity or lack of diversity of the citizenship of the parties."63 Thus federal jurisdiction depends on whether the action "arises under" the Lanham Act and not on whether the plaintiff's mark is registered.

Section 44 (h) provides that certain foreign nationals "shall be entitled to effective protection against unfair competition, and the remedies provided herein for infringe-

5 Ibid.

${ }_{33}{ }_{3}$ StAT. 728 (I905), as amended, 49 Stat. I921 (I936), 15 U. S. C. $\$ 97$ (I946); 36 Stat. Iog2 (Igri), 28 U. S. C. $\$_{4} \mathrm{I}(7)(\mathrm{r} 946)$.

ea 6 o STAт. 440 , I5 U. S. C. \$ri21 (1946).

a1 İbid. The Federal Judicial Code, effective September I, I948, also contains a further expression of the Congressional intent to broaden the jurisdiction of the federal courts in trade-mark and unfair competition matters. 28 U. S. C. $\$ 1338(b)$.

¿2 Armstrong Paint \& Varnish Works v. Nu-Enamel Corp., 305 U. S. 315 (1938).

${ }^{83}$ See note 60 supra. 
ment of marks shall be available so far as they may be appropriate in repressing acts of unfair competition." Section $44(\mathrm{~g})$ provides that "trade names or commercial names" of such foreign nationals "shall be protected without the obligation of filing or registration whether or not they form parts of marks." ${ }^{\prime 55}$ Section 44 (i) extends the benefits of Sections $44(\mathrm{~g})$ and $(\mathrm{h})$ to citizens or residents of the United States. ${ }^{60}$ It seems clear, therefore, that cases involving "effective protection against unfair competition," which would include all trade-mark and trade name cases, and cases involving protection of trade names or commercial names would be actions "arising under" the Lanham Act and would therefore be within the jurisdiction of the federal courts under Section 39 .

Not only do the words of Sections 39 and $44(\mathrm{~g})$, (h) and (i) require this construction, but any other construction would do violence to the intent of Congress stated in Section 45. Section 45 states that Congress intended to make "actionable the deceptive and misleading use of marks in ... commerce; to protect persons engaged in . . . commerce against unfair competition; ... and to provide rights and remedies ... respecting trade-marks, trade names and unfair competition. . . "07 The only place in which such conduct is made actionable and such protection, rights, and remedies are afforded in the case of unfair competition not involving registered marks is in Section 44, so that Congress must have intended that such cases should be actions arising under the Lanham Act and within the jurisdiction of the federal courts under Section 39 .

The only test of the jurisdiction of the federal courts is whether an action involves "commerce which may lawfully be regulated by Congress," since otherwise the action would not be one "arising under" the Lanham Act within the meaning of Section 39. The existence of federal jurisdiction thus depends upon whether the conduct involved or the parties to the cause of action are within or subject to the regulatory

64 60 STAT. 44I, 15 U. S. C. $\$ \operatorname{II26(h)~(1946).~"Persons~who~are~nationals~of,~domiciled~in,~or~}$ have a bona fide and effective business or commercial establishment in any foreign country, which is a party to $(I)$ the International Convention for the Protection of Industrial Property, signed at Paris on March 20, 1883; or (2) the General Inter-American Convention for Trade-Mark and Commercial Protection signed at Washington on February 20, 1929; or (3) any other convention or treaty relating to trade-marks, trade or commercial names, or the repression of unfair competition to which the United States is a party, shall be entitled to the benefits and subject to the provisions of this chapter to the extent and under the conditions essential to give effect to any such conventions and treaties so long as the United States shall continue to be a party thereto, except as provided in the following paragraphs of this section." 6o STAT. 44T, 15 U. S. C. \$1126(b) (1946).

¿T 60 STAT. 441 , I5 U. S. C. $\$ 1126$ (g) (1946).

08 "Citizens or residents of the United States shall have the same benefits as are granted by this - ons lascribed in paragraph (b) hereof." 6o STAT. 44I, I5 U. S. C. \$1126(i) (1946).

or 60 STAT. 443, 15 U. S. C. $\$ 1127$ (1946). In this last quotation reference to treaties and conventions is omitted, as such reference is descriptive rather than limiting. Section 44 of the Lanham Act specifies the "rights and remedies" under such treaties and conventions and then in Section $44(r)$ extends such rights and remedies to citizens and residents of the United States. The treaties and conventions are concerned only with the "rights and remedies" afforded citizens or residents of forcign countries, not the "rights and remedies" which the United States affords its own citizens or residents. The statement of intent is in better accord with the facts if the reference to treaties and conventions is construed as descriptive of the type of "rights and remedies" granted rather than as limiting the persons entitled to such "rights and remedies." 
power of Congress, and hence involves consideration of the scope of the commerce power. ${ }^{68}$

While the Lanham Act broadens the jurisdiction of the federal courts, nothing in the Act makes that jurisdiction exclusive even where registered marks are involved. The Lanham Act thus extends the jurisdiction of the federal courts without limiting the jurisdiction of state courts. However, for reasons which will later appear, this extension of federal jursidiction will probably result in the federal courts' becoming the only important forum in unfair competition matters.

III

\section{Rules of Decision in Federal Courts}

After the Erie decision it was clear that trade-mark and unfair competition cases which did not involve trade-marks registered under federal statutes were governed by state law. ${ }^{63}$ In cases involving registered trade-marks, federal law governed procedure and remedies, ${ }^{70}$ but there was a serious and difficult question whether the "substantive rights" of the parties were determined by federal or state law. ${ }^{71}$

As between state and federal law, the better rule was that announced by the Court of Appeals for the First Circuit, "that on the question of infringement of registered trade-marks the applicable law is federal statutory law, and where that is ambiguous or silent, federal case law . .."72 But application of this rule was not without difficulty. In the Seventh Circuit, federal law was held to apply only in situations involving " "passing off' effected solely by the use of a trade-mark"73; and even then federal law was not applicable "if either party's mark is used only in intrastate commerce, or if both marks are unregistered ... under the Act."74 In a suit for infringement of a registered trade-mark, the substantive rights of the owner of the mark could thus depend upon the extent and character of the defendant's activities rather than upon any absolute rights resulting from ownership of the registered mark.

Many, if not most, suits for infringement of a registered trade-mark include a count or claim for unfair competition. Ordinarily, in such an action the infringement count would be governed to some extent by federal law, and the unfair competition count would be governed exclusively by state law. ${ }^{75}$ However, at least one court

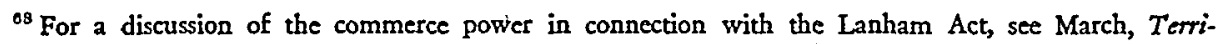
torial Scope of the Trade Mark Act of 1946, 38 T. M. Rep. 955, 965 (1948).

${ }^{\circ 0}$ Philco Corporation v. Phillips Mfg. Co., I33 F. 2d 663, 667 (C. C. A. 7th r943).

${ }^{70}$ Armstrong Paint \& Varnish Works v. Nu-Enamel Corp., 305 U. S. 315, 333 (I938).

${ }^{71}$ Dwinell-Wright Co. v. National Fruit Product Co., 140 F. 2d 6r8, 620 (C. C. A. Ist 1944); but see Folmer Graflex Corporation v. Graphic Photo Service, 44 F. Supp. 429, 432 (D. Mass. 1942). See criticism of the Folmer Graflex case in Zlinkoff, Erie v. Tompkins: In Relation to the Law of Trade-Marks and Unfair Competition, 32 T. M. Rep. 8I, ror (1942).

${ }^{72}$ Dwinell-Wright Co. v. National Fruit Product Co., supra note 7r, at 620 .

${ }^{75}$ Philco Corporation v. Phillips Mfg. Co., supra note 69 , at 672 .

7t Id. at 670 .

${ }^{75}$ Note 69 supra. The difficulties inherent in the application of laws of different sovereignties in the same case have been to some extent relieved by the fact that in some states the federal and state laws are identical. Gamlen Chemical Co. v. Gamlen, 38 T. M. Rep. 876 (W. D. Pa. 1948). But see note 8 supra. 
has held that an unfair competition count is also governed by federal law if jurisdiction of the count is ancillary to jurisdiction of a count for infringement of a registered mark, but is governed by state law if jurisdiction of the unfair competition count is based on diversity. ${ }^{76}$

This confusion, uncertainty, and conflict results from the effort to apply the Rules of Decision Act ${ }^{77}$ as interpreted in the Erie decision to the law of trade-marks and unfair competition. Because so much of present-day business is national in scope, the law of trade-marks and unfair competition does not lend itself to treatment on a local scale. The Lanham Act brings the whole field of trade-marks and unfair competition, with certain minor exceptions, into the exception in the Rules of Decision Act, and frees trade-mark and unfair competition actions from state law. The Lanham Act, in effect, eliminates the difficulties and uncertainties which resulted from application of the Erie doctrine in trade-mark and unfair competition cases.

The Rules of Decision Act provides that state law is to be applied in the federal courts, "except where the Constitution, treaties, or statutes of the United States otherwise require or provide. .."78 and the Lanham Act both requires and provides that the federal courts exercise their independent judgement in trade-mark and unfair competition matters.

By its terms, the Lanham Act covers the whole field of unfair competition, including infringement of trade-marks and trade names and other forms of unfair competition. Both the terms and the legislative history of the Act show that Congress intended that the law of unfair competition ${ }^{79}$ should be uniform throughout the United States. ${ }^{80}$ In the Philco case ${ }^{81}$ the court, discussing the Acts of 1905 and 1920, said: "The intention of Congress was to achieve uniformity within the area occupied. In so far as State law conflicts with this policy of the Trade Mark Acts, it must yield to the superior federal law." In the Lanham Act, Congress occupies the whole area of unfair competition, thus leaving little or nothing to the operation of state law, whether decisional or statutory. ${ }^{82}$

In addition to the fact that the congressional intent was to occupy the entire field, it should be noted that the protection to be afforded against unfair competition is a matter of interpretation and application of the Lanham Act and is therefore a matter in which the federal courts must exercise independent judgment, un-

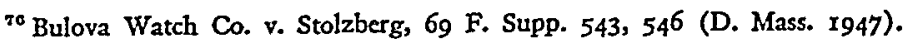

7 RiEv. STAT. $\$ 721$ (I875), 28 U. S. C. $\$ 725$ (I946).

${ }^{78}$ Ibid.

${ }^{70}$ The courts have held that federal law governs in cases involving trade-marks registered under the Acts of 1905 and 1920 . See notes 69,70 , and 71 supra. In this discussion, the cffects of the Lanham Act on the rules of decision in unfair competition cases will be considered since the changes made with respect to unfair comperition generally are more clearly applicable to cases involving registered marks.

${ }^{\text {Bo }}$ See, for example, Sen. ReP. No. 1333, 79th Cong., 2d Sess. (1946).

- ${ }^{81}$ Philco Corporation v. Phillips Mfg Co., 133 F. $2 \mathrm{~d} 663,672$ (C. C. A. 7 th 1943).

" 82 State law continues to govern purely local matters, but, as will be pointed out later, local matters which do not affect commerce may be so few as to be inconsequential. 
hampered by the statutes or decisions of the state in which the federal court sits. ${ }^{83}$ Cases involving registered trade-marks are specifically freed "from interference by State, or territorial legislation."84

The Lanham Act provides that trade names "shall be protected" 85 and that "effective protection" 86 shall be afforded against unfair competition. While it is true that the Act does not define "unfair competition," it is for the federal courts to find and decide the meaning of the term. It is for the federal courts to decide what acts constitute the "unfair competition" which the Lanham Act makes "actionable" and against which it provides "effective protection." Application of the laws of the particular state in which a federal court sits would do violence to the congressional intent to provide "national legislation along national lines." Thus the federal courts sitting in Illinois, for example, will not be limited to the Illinois "palming off" doctrine ${ }^{87}$ but will be bound by the broader federal interpretation of "unfair competition." 88

Not only does the Lanham Act require the federal courts to apply their own interpretation of the term "unfair competition," but the relief to be afforded is also a question of federal law. The Act provides that "the remedies provided herein for infringement of marks shall be available . . . in repressing acts of unfair competition." $\$$ These remedies include "injunctions, according to the principles of equity ... to prevent the violation of any right, ${ }^{290}$ and it is specifically provided that protection against unfair competition shall be "effective."91 The determination of the right, the need for protection, and the granting of effective relief are matters of interpretation and application of a federal statute, and are wholly independent of state law. ${ }^{92}$

The Court of Appeals for the Seventh Circuit stated in the Philco case that "The policy of a statute which Congress has enacted under its constitutional power to regulate interstate commerce may not be defeated or obstructed by State law, whether decisional ... or statutory . .. ${ }^{93}$ but held that application of the Acts of Ig05 and rg20 was limited to "that part of the field of unfair competition . . . having to do with 'passing off' effected solely by the use of a trade mark." 94 Whether or not the court was correct in its view of the scope of the Acts of 1905 and 1920, it was

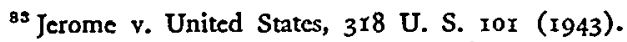

84 60 STAT. 443 , IIS U. S. C. \$II27 (I946).

sฐ 60 Stat. 44 , 15 U. S. C. $\$ 1126$ (g) (1946).

so 60 STAT. 44 r, I5 U. S. C. $\$ 1126$ (h) (1946).

${ }^{87}$ Time, Inc. v. Viobin Corporation, I28 F. 2 d 860 (C. C. A. 7 th r942).

${ }^{88}$ For example, International News Service v. The Associated Press, 248 U. S. 215, 236 (1918), identifies the right to protection against unfair competition as the right to protection in the conduct of a lawful business.

${ }^{80}$ See note 64 supra.

${ }^{00} 60$ STAT. 439 , I5 U. S. C. §III6 (1946).

${ }^{01}$ See note 86 stipra.

${ }^{03}$ In re Pittsburgh Railways, Co., I55 F. $2 d 477$ (C. C. A. $3 d$ I946), cert. denied, 329 U. S. 731 (ig16).

${ }^{03}$ Philco Corporation v. Phillips Mfg. Co., supra note 69 , at $67 x-672$.

os Id. at 672 . 
correct in its holding as to the effect of congressional action upon state law. The Lanham Act, however, covers the whole field of unfair competition, so that federal law is supreme in the field.

The extent to which particular acts or transactions will be subject to the Lanham Act-and hence the extent to which federal law governs-depends upon the scope given by the courts to the power of Congress over commerce. Where both parties to an unfair competition action are engaged in interstate or foreign commerce and the unfair competitive acts occur in that commerce, there is no difficulty in finding the Lanham Act applicable. The difficulty arises when at least one of the parties is engaged in a local business or the unfair acts are local. Prior to the Lanham Act, unfair competition cases reached the federal courts on diversity grounds ${ }^{05}$ and were subject to the vicissitudes of state law. Even federal registrations did not constitute a basis for relief against purely intrastate infringement. ${ }^{00}$

The commerce to which Congress made the Lanham Act applicable is "all commerce which may be lawfully regulated by Congress," to regulate competitive practices extends to matters which are wholly intrastate if they affect interstate commerce. ${ }^{98}$ The Lanham Act therefore applies whenever interstate or foreign commerce is affected, regardless of whether the business of one or both parties or the unfair acts are strictly local. In the Filburn case, ${ }^{\text {D9 }}$ the power of Congress was held to include control over wheat intended for consumption on the very farm where it was grown; a similar construction applied to the Lanham Act would make that Act applicable in almost every conceivable situation.

Since unfair competition is a violation of the right to conduct a lawful business, ${ }^{100}$ it necessarily affects every part of the business. For example, in the simplest form of unfair competition-passing off-the deception not only affects the business which is directly injured but also necessarily affects both the customers and suppliers of that business. To the extent that such customers or suppliers are engaged in interstate or foreign commerce, such commerce will be affected regardless of the character of the business against which the unfair competition is immediately directed.

So far as the federal courts are concerned, there will probably be few, if any, situations in which state law will be applied in an unfair competition case. Jurisdiction will ordinarily be based upon the Lanham Act itself or upon diversity of citizenship. If jurisdiction is based upon the Lanham Act, that Act will apply; while if a citizen of one state is competing unfairly with a citizen of another, com-

os Armstrong Paint \& Varnish Works v. Nu-Enamel Corp., supra note 70.

${ }^{\circ 0}$ See March, supra note 68 , at 962 .

${ }^{97} 60$ Stat. 443,15 U. S. C. $\$ 1127$ (1946).

${ }^{98}$ In United States v. Wrightwood Dairy Co., 315 U. S. 110, 120 (1942), Chicf Justice Stone said: ". . . the marketing of a local product in competition with that of a like commodity moving interstate may so interfere with interstate commerce or its regulation as to afford a basis for Congressional regulation of the intrastate activity. It is the effect upon the interstate commerce or its regulation, regardless of the particular form which the competition may take, which is the test of federal power."

${ }^{00}$ Wickard v. Filburn, 317 U. S. III (1942).

${ }^{100}$ See note 88 supra. 
merce within the regulatory power of Congress will almost invariably be involved. It is theoretically possible that a case of purely local unfair competition could be ancillary to a cause of action within the jurisdiction of the federal courts and therefore be triable in the federal courts, but such cases will probably be few. ${ }^{101}$

IV

\section{State Laws}

The Lanham Act not only eliminates the effects of the Erie decision in the federal courts, but makes state law wholly ineffective in all cases of unfair competition in commerce subject to the power of Congress. While it is true that "as a matter of statutory construction Congressional intention to displace local laws in the exercise of the commerce power is not, in general, to be inferred unless clearly indicated by those considerations which are persuasive of the statutory purpose," 102 the statutory purpose of the Lanham Act to displace local laws is clear. So far as registered marks are concerned, that purpose is expressly stated. ${ }^{103}$

In cases of unfair competition generally, the congressional purpose was to provide uniformity in place of conflict and confusion. ${ }^{104}$ The commerce clause of the Constitution ${ }^{105}$ is not only a grant of power to Congress but is a limitation on the power of the states, ${ }^{106}$ and state laws cannot interfere "in matters with respect to which uniformity of regulation is of predominant national concern."107 Where the policy of Congress is to provide uniform regulation for the entire field of unfair competition, state law, whether coinciding with or opposing the federal law, is ineffective $^{108}$ even in those situations which are subject to the regulatory power of Congress but are not specifically regulated. ${ }^{109}$

The state laws most obviously affected by the Lanham Act are the trade-mark registration statutes of the various states. These registration statutes have never been mandatory, ${ }^{110}$ and, since the Lanham Act became effective, it is extremely doubtful that state registration laws could be made mandatory as against marks used in commerce within the regulatory power of Congress. Certainly no state

${ }^{101}$ Musher Foundation, Inc. v. Alba Trading Co., 127 F. $2 d 9$ (C. C. A. $2 d$ 1942), cert. denied, 3I7 U. S. 64I (1942); Zalkind v. Scheinman, 139 F. 2d 895 (C. C. A. 2d 1943), cert. denied, 322 U. S. 738 (r943). But see 28 U. S. C. $\$ 1338(\mathrm{~b})$.

${ }^{103}$ Maurer v. Hamilton, 309 U. S. $598,6 \mathrm{r}_{4}$ (1940).

${ }^{103} 60$ STAT. 443 , I5 U. S. C. \$1127 (1946).

206 The confusion and conflict in the unfair competition laws of the various states was one of the principal grounds urged in support of a federal law of trade-marks and unfair competition (see note 27 supra) and the need for uniform legislation was one of the prinicpal reasons urged for passage of the Lanham Act. (See note 4I supra.) There is certainly no indication that Congress intended that state law should continuc to be applicable, and, in the absence of such an indication, a Congressional intent that the Lanham Act shall apply uniformly is to be implied. Jerome v. United States, 3I8 U. S. ror (r943). See also Clearfield Trust Co. v. United States, 318 U. S. 363 (1943).

${ }^{100}$ U. S. Const. Art. I, $\$ 8$.

${ }^{100}$ Frecman v. Hewit, 329 U. S. 249, 252 (1946).

${ }^{107}$ Southern Pacific Co. v. Arizona, 325 U. S. 76I, 700 (I945).

${ }^{108}$ Charleston \& W. C. Ry. v. Varnville Furniture Co. 237 U. S. 597 (I915).

${ }^{100}$ Bethlehem Steel Co. v. New York Labor Relations Board, 330 U. S. 767 (I947).

${ }^{130}$ I7 J. PAT. OFF. Soc'Y 120, 133 (1935). 
could, require registration of a "registered mark" as defined in the Lanham Act, 111 because the Act expressly frees such marks from interference by state or territorial legislation. ${ }^{112}$ Marks which are not "registered marks" but which are used in commerce subject to the control of Congress, while not exempted from state laws by specific provision, are exempt from interference from such laws by necessary implication. Compulsory state registration would place a burden on users of such marks; $;^{113}$ and no state can lawfully impose such a barrier against, or impose such a burden on, interstate or foreign commerce. ${ }^{114}$

A state may provide for registration of trade-marks used in the state, and may also specify the rights of the registrant and remedies for infringement. However, even before the passage of the Lanham Act, state registrations were of doubtful value against interstate users. ${ }^{115}$ The Lanham Act protects and preserves trademark rights existing prior to its effective date, ${ }^{116}$ but after that date the effectiveness of a local trade-mark against an interstate user will probably be governed by the Lanham Act.

The definition of "trade names" in the Lanham Act" ${ }^{117}$ is broad enough to include corporate names. Corporate names are a matter of state corporation law, but in so far as use of a corporate name affects or is affected by a trade-mark or trade name in commerce within the meaning of the Lanham Act, the provisions of the Lanham Act will control. The Lanham Act, by affording protection for trade names, ${ }^{118}$ protects corporate names, and prior users of trade names or trade-marks are protected against subsequently adopted similar corporate names on several grounds.

In the first place, the common law afforded protection against corporate names which might cause confusion or mistake or deceive purchasers. ${ }^{110}$ In addition, the Lanham Act provides that trade names shall be protected, and federal power to enjoin use of particular corporate names as competitive devices has been clearly established. ${ }^{120}$. As stated by Mr. Justice Murphy, the Federal Government

.. may compel changes in the voting rights and other privileges of stockholders. It may order divestment or rearrangement of property, it may order the reorganization or dissolution of a corporation. In short, Congress is completely uninhibited by the commerce clause in selecting the means considered necessary for bringing about the desired conditions in the channels of interstate commerce. ${ }^{121}$

${ }^{111}$ See notes 53 and 55 stzra.

113 See note 86 supra.

113 See notes 24 and 25 supra.

114 Nippert v. Richmond, 327 U. S. 416 (I946). See also Coca-Cola Co. Y. State, 225 S. W. 791 (Tex. Civ. App. 1920).

${ }^{125}$ Coca-Cola Co. v. Stevenson, 276 Fed. roro (D. C. Ill. 1920). See also Gibbons v. Ogden, 9 Wheat. I (U. S. I824).

${ }^{126} 60$ STAT. 427 , I5 U. S. C. note following \$1051 (1946).

${ }^{117}$ See note 56 supra.

${ }^{118}$ See note 65 supra.

${ }_{119}$ Charles Burke Elliott, A Treatre on the Law of Pruvate Corporations 43, 44, 45 (1923).

${ }^{120}$ Federal Trade Commission v. Pure Silk Hosiery Mill, 3 F. 2 d ro5 (C. C. A. 7th 1924).

131 American Power \& Light Co. v. Securities and Exchange Commission, 329 U. S. 90, 99 (1946). 
If the power of Congress extends to reorganization or dissolution of a corporation created by the state, a fortiori it extends to protecting or enjoining the use of a particular corporate name.

Prior to passage of the Lanham Act, there was nothing to detract from the jurisdiction of state courts over actions involving trade-marks or unfair competition, ${ }^{122}$ and the Lanham Act makes no change in this regard. However, the Lanham Act and decisions of the federal courts construing it will be binding upon state courts in cases involving unfair competition within the scope of the Act. For example, a state court will be obliged to give to a certificate of registration the evidentiary value provided in the Lanham $\mathrm{Act}^{123}$ and to afford against unfair competition relief which would be "effective" in accordance with the decisions of the federal courts. $^{124}$

The extent of this change is in some instances radical and striking. Instead of the federal courts sitting in Illinois being bound by the obsolete Illinois rule that "passing off" is the only actionable form of unfair competition, ${ }^{125}$ the courts of Illinois will be obliged to apply the more modern, more flexible federal rule that interference with the right to conduct a lawful business is actionable. ${ }^{126}$

Even in cases which are wholly local, the probability is that state courts will apply the law of unfair competition as it is applied in the federal courts. State courts are obliged to apply that law in cases involving citizens of other states, and to deny their own citizens the same rights would be a discrimination in favor of outsiders. Such rulings would be at once unfair, unrealistic, and impolitic.

\section{$\mathrm{V}$}

\section{Preservation of Existing Rights}

Prior to the effective date of the Lanham Act, common-law trade-mark rights were, in the absence of conflicting rights of others, coextensive with the use made of the mark. The Act of I905 preserved common-law rights whether existing at the time of the Act or acquired thereafter. ${ }^{127}$ Not infrequently, different persons owned identical marks for identical goods in different parts of the United States, ${ }^{128}$ and it is probable that there are many marks which are used-and therefore owned -for marketing areas confined to one or a few states. Such trade-mark rights, however limited geographically or otherwise, are none the less property rights ${ }^{129}$ entitled to recognition and protection.

${ }^{222}$ There is nothing in the federal law of trade-marks comparable to the law relating to patents. See 28 U. S. C. $\$ 37$ I.

${ }^{123} 60$ STAT. 438 , I5 U. S. C. \$III5 (1946).

124 U. S. Const. Art. VI.

${ }^{125}$ See notes 37 and 87 supra.

${ }^{120}$ See note 90 supra.

${ }^{127} 33$ STAT. 730 (1905), I5 U. S. C. \$103 (1946).

${ }^{228}$ Hanover Star Milling Co. v. Metcalf, 240 U. S. 403, 413 (1916); United Drag Co. v. Rectanus, 238 U. S. 90,97 (r9r8).

120 Hanover Star Milling Co. v. Metcalf, supre. 
The Lanham Act provides that "Registration of a mark on the principal register provided by this Act or under the Act of March 3, 188I, or the Act of February 20, I905, shall be constructive notice of the registrant's claim of ownership."130 Such registration is evidence of the "registrant's exclusive right to use the registered mark"131 in "all commerce which may lawfully be regulated by Congress."132 Thus the Act gives a registrant at least pre-emptive trade-mark protection throughout the United States ${ }^{133}$ and makes the registration notice of that fact. For this reason it is substantially impossible, since the effective date of the Lanham Act, to acquire local rights in conflict with a registered mark, even in an area not yet invaded by the registrant. ${ }^{134}$

There is no constitutional difficulty in legislation which prevents future conflicting local trade-mark rights; but in providing national legislation Congress could not constitutionally destroy existing trade-mark rights. ${ }^{135}$ To avoid this constitutional difficulty, the Act preserves pre-existing trade-mark rights by providing that "Nothing herein shall adversely affect the right or the enforcement of rights in marks acquired in good faith prior to the effective date of this Act."130 In addition to this general preservation of trade-mark rights, the Act offers specific benefits and protection for certain types of pre-existing rights ${ }^{137}$ and protects such rights from the effects of even incontestable registrations. ${ }^{138}$

Where different persons had rights in identical marks for identical goods in different parts of the United States, the rights of each such person in its own mark were coextensive with the territory in which the mark was used; but only the first user could register under the Act of $1905 .{ }^{139}$ Even when a mark was registered under the Act of 1905 , a subsequent user could, by use of a mark identical with a registered mark, obtain rights in such mark in territory in which the registrant had not used his mark. ${ }^{140}$

In maintaining the exclusive features of pre-existing trade-mark rights, the Lanham Act preserves the common-law rights of trade-mark owners against infringe-

${ }^{230} 60$ STAT. 435,15 U. S. C. $\$ 1072$ (1946).

${ }^{131} 60$ STAT. 438 , 15 U. S. C. $\$ 1 \times 15(1946)$. The certificate of registration is prima facie evidence of this right if the mark is not incontestable. 60 STAT. 438,15 U. S. C. $5 \operatorname{1r} 5$ (b) (1946).

${ }^{132} 60$ STAT. 443 , I5 U. S. C. $\$ 1127$ (1946).

${ }^{133}$ March, supra note 69 , at 957 .

134 The right to continue to use such a local mark could be secured by laches or estoppel, since Section 34 provides for the granting of injunctions "according to the principles of equity." However, such a local use could not support even concurrent registration since a concurrent registration of a mark must be based upon "concurrent lawful use thereof in commerce prior to any of the filing dates of the applications involved." Sec. 2(d).

${ }_{13 E}$ U. S. CONST. AMEND. V.

${ }^{130} 60$ STAT, 427 , I5 U. S. C. note following $\$ 105 \mathrm{~T}$ (1946).

${ }^{237}$ Concurrent registrations. 6o STAT. 428, 15 U. S. C. $\$ 1052$ (d) (1946).

${ }^{138} 60$ STAT. 438,15 U. S. C. $\$ \operatorname{IrI5}($ b) (5) (1946). The wording of this section is not entirely clear. See Diggins, The Lanham Trade-Mark Act, 37 T. M. Rep. 36 (1947). But the ambiguity should present no particular dificulty when construed in the light of Sec. 49. See also Sec. 33(b)(6), 60 StAT. 438, 15 U. S. C. $\S \operatorname{III}(\mathrm{b})(6)(1946)$.

${ }^{139}$ Act of 1905, 33 Stat. 725 (1905), as amended, 43 Stat. 647 (1924), I5 U. S. C. \$85 (1946).

${ }^{240}$ United States Printing and Lithographing Co. v. Griggs, Cooper \& Co., 279 U. S. 156 (1929). 
ment. Even registered marks which are otherwise incontestable may infringe "a valid right acquired under the law of any State or territory,"141 and if a registered mark which is otherwise incontestable may infringe such a right, a fortiori a mark which is not incontestable might also infringe. In such a situation, the acquisition and validity of the right, since its existence depends upon state or territorial law, would necessarily be determined in accordance with that law. The issue of infringement however, involves interpretation of the Lanham Act since determination of the "extent" of infringement determines the extent of incontestability. ${ }^{142}$

The Lanham Act affords additional protection for existing common-law rights by providing that where limited marks have been used concurrently, both may be registered so long as each is limited to its previous use. ${ }^{143}$ Such concurrent registrations may be granted only when continued use of the marks is unlikely to cause confusion, mistake, or deceit of purchasers, and the registrations must contain "conditions and limitations" necessary to maintain such distinctions. ${ }^{144}$ The evidentiary effect of such concurrent registrations is limited by such "conditions and limitations," $"$ and presumably the constructive notice effect ${ }^{146}$ is similarly limited.

Concurrent-use registrations under the Lanham Act in effect preserve the exclusive features of certain pre-existing trade mark rights; but in addition, the Act provides for continuation of pre-existing rights to use marks. The exclusionary right is somewhat limited, but the defensive right as against registered marks which have not become incontestable is quite broad. Against registered marks which are not incontestable an infringer may rely upon "any legal or equitable defense or defect which might have been asserted if such mark had not been registered."147 The Act does not specify what constitutes a "legal or equitable defense or defect," but the determination whether particular facts constitute a "defense or defect" within

141 Sec. I5, 60 Stat. 433 , I5 U. S. C. $\$ 1165$ (1946).

${ }^{142}$ To leave the issue of infringement of state or territorial marks to state or territorial law would destroy the uniformity which the Lanham Act sceks. For example, there could be trade-mark rights in two states antedating the registered mark. If one of the two states follows a strict "passing off" theory of infringement and the other follows the "dilution" theory (Tiffany \& Co. v. Tífany Productions, Inc., 262 N. Y. 482,188 N. E. 80 (I932)), a registered mark might "infringe" to a different extent in cach state and hence, under $\$ 15$ of the Lanham Act, be "incontestable" to a different extent in each of the two states.

${ }^{113}$ Secs. 2(d), 7(a), 60 STAT. 428, I5 U. S. C. 51052 (d), 60 StaT. 430, I5 U. S. C. \$1057(a) (1946). See Diggins, The Lanham Trade-Mark Act, 37 T. M. Rep. 305 (1947). The Act does not in terms limit concurrent registrations to territorially limited marks and indicates that marks which differ as to "mode or place of use" or goods may be registered coneurrently. Sec. 2 (d). However, differences in mode of use or goods would make confusion, mistake, or deceit of purchasers unlikely, and the Patent Office in acting upon applications for registration is apparently construing the concurrent-use provisions of the Lanham Act as differing from prior law only in permitting concurrent registrations of marks used in different territories. Derenberg, The Lanham Act of 1946, Practical Effects and Experiences After One Year's Administration, 38 T. M. Rep. 83r, 849 (1948), states: "The basic idea of Sec. 2(d) . . was to permit registration of marks concurrently used in different parts of this country ..." See also Halliday, Geography of Trade-Marks, Concurrent Use and Registrations (Practising Law Institute Lecture, Dec. 4, 1947.)

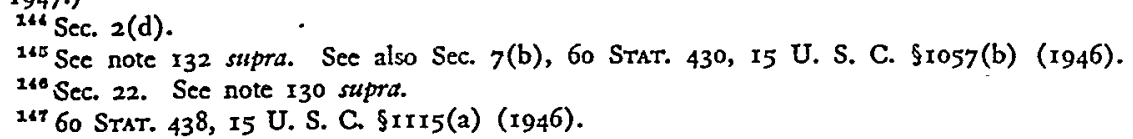


the meaning of the Act involves construction of a federal statute and is therefore a matter for the independent judgment of the federal courts. ${ }^{148}$

There may be some question whether recourse to state law would be necessary in the case of some types of "defect." Prior to the effective date of the Lanham Act, acquisition of trade-mark rights "rested upon the laws of the several states."140 If the defect relied upon were a defect in the acquisition, it would seem to be essential to examine the law of the state under which the mark was acquired to determine whether the acquisition was in fact defective.

As pointed out above, valid local rights acquired prior to publication of a registered mark are effective against the "right of the registrant to use" such mark, ${ }^{150}$ and such local rights also constitute a defense against "the registrant's exclusive right to use"151 such mark even though the registration may have become incontestable. This defensive effect of such marks is, unlike the exclusionary effect described above, ${ }^{152}$ a matter of federal rather than state law. The Lanham Act specifies the conditions under which and the extent to which such local marks constitute a defense against an incontestable registration, so that the defense involves interpretation and application of the Act itself.

\section{VI \\ UNFAIR COMPETITION}

The establishment of a substantive federal law of unfair competition does not present the same constitutional difficulty as a substantive federal law of trade-marks because, while trade-mark infringement is a species of unfair competition, specialized legal rules and concepts have been developed for the protection of trade-marks. ${ }^{163}$ Even local trade-marks are property which Congress cannot constitutionally destroy; but while one may have a right to compete with another, no one has or can have a vested right to compete unfairly. From time to time federal laws ${ }^{154}$ have prohibited various forms and types of unfair competition; ${ }^{\mathbf{1 5 5}}$ and the prohibitions of these laws have been effective even in instances where most or all of the acts constituting the prohibited practice have preceded the effective date of the federal law. ${ }^{\text {two }}$

The Lanham Act merely makes unfair competition a matter of federal law and leaves it to the federal courts to determine what competitive acts, conduct, or prac-

${ }^{218}$ Jerome v. United States, supra note 83 .

${ }^{140}$ American Trading Co. v. Heacock Co., 285 U. S. 247,258 (r932).

${ }^{100}$ Sec. 15.60 STAT. 433 , I5 U. S. C. $\$ 1065$ (1946).

${ }^{15 x}$ Sec. 33. 6o Stat. 438 , 15 U. S. C. \$1115. (1946).

${ }^{152}$ Sec. 33 (b) (5). 60 STAT. 438, 15 U. S. C. \$1175(b)(5) 1946.

18s "The infringement of a trade-mark, for instance, is conceived as an invasion of property. . . Unfair competition, on the other hand, cannot be placed on the plane of invasion of property right. This tort is strictly one of fraud, and a fraudulent intent or its equivalent is essential to liability." I 'Tном Atkins Street, The Founditions of Legal Liability 421 (rgo6).

254 The principal examples are the Sherman Act, 26 STAT. 209 (1890), as amended, IS U. S. C. \$1 (1946); the Clayton Act, 38 STaT. 730 (1914), 15 U. S. C. \$12 (1946); and the Federal Trade Com. mission Act, 38 STAT. 717 (1914), as amended, I5 U. S. C. \$4I (1946).

${ }_{165}$ Handler, Unfair Competition, 21 IowA L. Rev. 175, 214 et seg. (1936).

${ }^{150} \mathrm{Cf}$. United States v. Pullman Co., 64 F. Supp. 108 (E. D. Pa. 1946). 
tices are "unfair." The Act does not in terms prohibit or make actionable acts or practices which were lawful when done, but, in effect, provides that there shall be a uniform federal law of unfair competition. Unfair competition is actionable at common law, ${ }^{157}$ and a change in the scope of actionable unfair competition by judicial decision, even though retrospective in effect, would not be unconstitutional. $^{158}$

\section{VII}

\section{Conclusion}

The Lanham Act provides a uniform federal law of trade-marks and unfair competition which is controlling in all cases and situations affecting interstate or foreign commerce. The ever-expanding judicial concept of the commerce power of Congress makes the Act effective in substantially all trade-mark and unfair competition cases without recourse to state law. The Act eliminates most of the effects of the Erie decision in trade-mark and unfair competition cases, and thereby eliminates the uncertainty and confusion which resulted from the application of state law.

So far as trade-marks are concerned, the Lanham Act recognizes, preserves, and protects trade-mark rights existing at the effective date of the Act. To a limited extent, these rights necessitate recourse to the laws of the states under which such rights exist. However, as time passes, trade-mark rights existing at the effective date of the Act will probably either fall into disuse or qualify for registration and be registered under the Lanham Act. The Act is so drafted that, after a relatively few years, it may be expected that the state law of trade-marks and unfair competition will be of little more than historical interest.

${ }^{157}$ Handler, supra note 155, at 179 et seq.

${ }^{168}$ Cf. United States v. General Electric Co., 80 F. Supp. 989 (S. D. N. Y. 1948). 